\title{
Avaliku ruumi mõiste areng ja tähendusväljad
}

\author{
ANTTI ROOSE, HELEN SOOVÄLI-SEPPING, ANNI MÜÜRIPEAL
}

Eesti ühiskond pöörab üha enam tähelepanu meie igapäevasele elukeskkonnale. Ka ühiskonna demokraatlikud protsessid, mis liiguvad kord avatuse ja sidususe, siis jälle sulgumise ja eraldatuse poole, on toonud eesti keelde uusi sõnaühendeid. Üks nendest on avalik ruum. Ruumi mõiste kasutamine ja sidumine omadussõnaga avalik ei ole ainult keelefilosoofiline küsimus, vaid katse jõuda ühisele arusaamale meid ümbritsevast ruumist ja selle kasutusest. Seejuures tuleb arvestada mõiste mitmetähenduslikkust: ruum esineb nii argi- kui ka teaduskeeles abstraktse, keskkonna- ja ühiskonnateadusliku mõistena. Eesti keeles ei ole termin avalik ruum veel juurdunud. Näiteks ei esine see Eesti Keele Instituudi (EKI) mitmekeelses terminibaasis (Esterm). Niisamuti ei leia seda sõnapaari andmebaasist „EKI ühendsõnastik 2020”.

Küll on mõistelist selgust loomas teadlaskond, niisamuti kodanikuaktivistid, kes seisavad kvaliteetsema avaliku ruumi eest. Seegi artikkel lähtub 2019/2020. aasta Eesti inimarengu aruandest „Linnastunud ühiskonna ruumilised valikud” (SooväliSepping 2020), milles on olulisimal kohal avalik ruum. Inimarengu aruanne kui olemuselt ülevaatekogumik (24 artiklit 39 autorilt) sisaldab Eesti kõige värskemaid ja aktuaalsemaid avaliku ruumi käsitlusi, mis ühtlasi raamistavad siinset artiklit.

Avaliku ruumi mõiste käsitlemisel piirdume järgnevalt geograafia ja kitsamalt linnauurimuslike suundadega, mis esindavad tänapäeva kodanikuühiskonna avaliku ja linnaruumi vaatenurki. Samuti hõlmab arutelu ehituse ja arhitektuuri valdkonda. Anname ülevaate mõiste avalik ruum käsitlusest ruumiteadustes ning selle ühiskondlikust olulisusest, samuti analüüsime mõiste tähendusvälju ja kirjeldame selle kasutuskontekste. Peame oluliseks rõhutada, et me ei püüa täpselt määratleda teaduslikku terminit, vaid soovime ärgitada arutelu selle üle, kui muutlik on eestikeelse avaliku ruumi mõiste tähendusväli erialakeeltes.

Ühiskondlik arutelu avaliku ruumi üle, linnaruumi füüsiline areng, linnaplaneerimine ja investeeringud avalikku ruumi on järsult elavnenud nii Eestis kui ka mujal maailmas. Avaliku ruumi loome pole mitte ainult moes, vaid on programmiline linnapoliitika; iseäranis suurlinnades, näiteks Londonis ja New Yorgis, on varasemast olulisem kohakesksus, mis seostub linnakujunduses jalakäijate eelistamisega autodele (Madden 2017). Sarnaseid näiteid leiab Eestistki. Eesti Vabariigi 100. sünnipäeva auks tehti EV100 arhitektuuriprogramm „Hea avalik ruum”, mille alusel ehitati, uuendati ja taaskäivitati 15 linna keskused, peaväljakud, peatänavad ja nendega piirnevad alad. Peale teema tähtsustumise on avaliku ruumi olemus teinud Eestis viimastel kümnenditel läbi suure muutuse. Ühelt poolt toimub avaliku ruumi erastamine ning teiselt poolt on vaja linnakeskkonda ja elukvaliteeti parandada linnaarenduses, täpsemalt avaliku ruumi loomes. Avaliku ruumi eestikeelne mõtte- 
lugu ja selgitus areneb kohaliku ja üleilmse avaliku ruumi arengu tuules. Siit ka põhjendus järgnevateks lehekülgedeks, mis selgitavad, kuidas avalikku ruumi paremini mõista ja mõtestada ning edendada nii füüsilises, geograafilises keskkonnas kui ka eesti keelekeskkonnas.

12. märtsil 2020 välja kuulutatud eriolukorra ja liikumispiirangutega sai avalik ruum seninägematult oluliseks, ühekorraga isikuvabaduse ja avalikkuse kehastuseks. Valitsus kehtestas 2+2 reegli, mille kohaselt tuli avalikes kohtades hoida teiste inimestega vähemalt kaks meetrit vahet ja koos tohtis viibida kuni kaks inimest (Kriis.ee). See reegel teadvustas teravamalt kui kunagi varem avaliku ruumi mõistet ühiskonnas. Mõiste tõlgendamine väljus akadeemilistest ja poliitilistest aruteludest ning osutus iga inimese argielu küsimuseks: kuidas käituda, tegutseda ja olla üldkasutatavas kohas?

\section{Avaliku ruumi mõiste kujunemine}

Sõltuvalt teemast kasutavad linnauurijad kõrvuti nii kirjeldavat, juhusliku tähendusväljaga kui ka kitsast ja konkreetset mõistet. Avaras tähenduses on avalik ruum subjektiivne: see sõltub kasutajast ning seda tajutakse ja kogetakse ennekõike individuaalselt. Kitsamas kasutuses tuleneb mõiste tähendusväli kas tsiviilõigusest ja linnakorraldusest või konkreetsest uurimisfookusest ja -objektist, näiteks piiritletakse mõistet füüsiliselt ja ruumiliselt või sotsiaalteaduste ja ühiskonnauuringute võtmes. Füüsilises ruumis piisab, kui üksi elav inimene kutsub koju külalise ning juba on loodud teatud ajaks ja teatud inimestele avalik ruum (Lapin 2014). Kitsam mõiste märgib avaliku ruumi laiema käsituse objektiivseid omadusi ja ilminguid ning sellega seotud kokkuleppeid. Sellest, kuidas on defineeritud avalik ruum, kui laialt või kitsalt seda mõistetakse, sõltub, kuidas avalik ruum teostub, kuidas ühiskond seda tajub, kogeb, kasutab ja väärtustab. Avalik ruum moodustub subjektipõhiselt ning on ühiskondlike protsesside ja otsuste taust või osa. Jüri Soolep (2011: 7) on ruumi olemuse sõnastanud järgmiselt: „Enamus majanduslikke, ideoloogilisi, teoloogilisi ja poliitilisi sündmusi evib ruumilist vormi või dimensiooni, või kõige lihtsamalt öeldes, kui nad ka ei oma nähtavat ruumilist dimensiooni, siis nad ometi kõige üldisemal viisil toimivad ruumis."

Mis on need ruumilised, sotsiaalsed ja ühiskondlikud tunnused, mis avalikku ruumi väljendavad? Teadlased on paljudel juhtudel tõstatanud küsimuse avatuse ja avalikkuse varjunditest. Avatus ja avalikkus ei ole kunagi täielikud ning sõltuvalt ruumi tüübist, iseloomust, geograafilisest asukohast ja kasutajast avalduvad nende erisused teljel avatud-poolavatud-suletud/eraruum. Sellest tulenevalt seatakse avaliku ruumi avatusele ka ametlikke või kogemuslikke ehk käitumisnormilisi piiranguid. Näiteks linna keskväljakul ja linnarannas käitub inimene teistmoodi kui isiklikus ruumis. Kõige üldisemalt tähistab avaliku ruumi mõiste ühist ruumi, mis pälvib avalikku tähelepanu ja pakub ühiskondlikku hüvet.

Rahvusvahelises teaduses muutus avalik ruum peavoolu uurimisteemaks 1990. aastate teisest poolest alates ning nüüdseks on autorkond aina laienenud, artiklite 
arv kasvanud ja teemakäsitlus avardunud. Avalik ruum pürib üheks olulisemaks valdkondadevaheliseks uurimisteemaks, mis on asetatud humanitaar- ja ühiskonnateadustes XX sajandi lõpukümnenditel toimunud ruumilise pöörde konteksti (Lefebvre 1991; Sooväli-Sepping 2011). Avaliku ruumi mõiste ja selle selgitamise üle on juurelnud ruumi- ja keskkonnateadlased, sotsioloogid, antropoloogid ja psühholoogid. Ka rahvusvahelise säästva arengu poliitika dokumendid käsitlevad avalikku ruumi ja selle olulisust inimese elukvaliteedile (vt nt Muudame maailma: 19).

Loetletud suundumustele tuginedes võib väita, et avaliku ruumi tähendusväli on laienemas ega piirdu avaliku füüsilise linnaruumiosaga, vaid see hõlmab kõigile ligipääsetavat ja võõraste inimeste kohtumise ruumi, seda kõikvõimalikes kodanikuühiskonna ja sotsiaalsete protsesside avaldustes (Parkinson 2013). Täpsustades lähteküsimust, mi s on avalik ruum, tuleb peale selle kindlasti küsida ja ka mõiste tähendusvälja kindlaks määramiseks välja selgitada, ku s on avalik ruum, kelle le on see ligipääsetav ja $\mathrm{m}$ i d a tohib seal teha.

\subsection{Avalik ruum versus privaatne ruum}

Esmalt mõistetakse avalikku ruumi privaatse ehk eraruumi vastandina. Vastandus ja vastandmõiste kaudu selgitamine loob küll mõiste tähendusest ettekujutuse, kuid tekitab uue küsimuse, mis on privaatne (Low, Smith 2006). Avaliku-privaatse kahendsüsteem lähtub liberaalsuse kontseptsioonist, millel rajaneb suuresti nüüdisaegne lääne demokraatia. Avalik on kõik see, mis pole eraviisiline. Keelelist segadust tekitab avaliku vastandsõna era, mis tahaks laiendit (nt eraviisiline, erakasutuslik või eraõiguslik). Küsimus ei piirdu omandisuhte ega valdusega, vaid puudutab kollektiivset ja individuaalset ruumikasutust. Avalik võib tähendada ka ühist hüvet, mis on võrreldav puhta õhu või ühistranspordiga.

Sõnade eraviisiline ja privaatne sage kasutamine ei selgita täpselt, mil määral kätkeb eraruum ka avalikkust. Eraomandil ja eravaldusel, isegi kodul võib juriidiliselt olla avalikkuse jaoks huviväärne mõju ühisele ruumikasutusele, näiteks külgnevuse ja naabrussuhte tõttu. Väljend „minu kodu on minu kindlus” ei tarvitse kehtida sada protsenti. Peale selle ei saa seda ütlust käsitleda vaid nii, et hoonestik on eraruum ja seda ümbritsev on avalik ruum. Samuti pakub linna avalik ruum ühise hüvena loomulikku üleminekut ühest linnaruumi otstarbest teise, olles näiteks ärimaa ja elamumaa vaheline puhvertsoon.

\subsection{Avalik ruum arhitektuuriteoorias ja linnauurimuses}

Vanim säilinud arhitektuuriteooria tekst, 30.-15. aastal eKr kirjutatud Vitruviuse „De architectura” („Arhitektuurist”) käsitleb ruumi füüsilisena ja selgelt piiritletuna. Avalike (arhitektuuri)töödena on teoses käsitletud kaitserajatisi, sakraalehitisi, avalike teenuste hooneid ja alasid, nagu sadamad, linnaväljakud (it fora), teatrid, termid ja promenaadid (Meyers 2005). Loetletud avalikud rajatised oli arhitekt kavandanud tellija nägemuse järgi ja need kandsid samal ajal nii funktsionaalset kui ka sümboolset tähendust. Tellija oli võimul olev valitseja. Kui Vitruvius kirjutab Itaaliast ja 
Roomast, siis samasugust arhitekti, tellija ja ruumi suhet Eestis on käsitlenud Mart Kalm (2014), kes kirjeldab kesklinna arhitektuuri kui võimuakti, mis võimaldab ideoloogial end linnaruumis kehtestada kauemaks, kui see ise kestab. Sellises käsitluses on ruum avalik, kui see on avatud liikumiseks ja kogunemiseks. Vastukaaluks tekkis 1970. aastatel Kesk- ja Lääne-Euroopas rühmitusi, kes kritiseerisid ühiskonna vaikivat nõusolekut kapitalismi ja tehnokraatiaga (Kaminer 2017). See tähendas, et kohalike kogukondade, looduskeskkonna ja eluruumide vähesusega mitte arvestavate arhitektuuriprojektide alternatiivina mõeldi välja ruumilisi struktuure, mida võis rajada igaüks (täispuhutavad, ise tehtavad ja ajutise kasutuse arhitektuuriobjektid) (Kaminer 2017). Avalikkus sai ruumis laiendatud tähenduse: peale ligipääsetavuse kätkes see ka võimalust luua linnaruumi ise, vahetult, nii füüsiliselt kui ka sümboolselt.

Tulles kahest osast koosneva mõiste põhisõna juurde, küsime: mis on ruum? Inimgeograafias väljendab ruum (ingl space) füüsilist üksust, mille sotsiaalse kasutusega saadakse koht (ingl place) (Agnew 1987: 26; Gieryn 2003; vt ka Neal 2010; Augé 2012). Arhitektuuriteoorias on koha ja ruumi mõistmine vastupidine: koht on füüsiline sisult ja vormilt, muutudes ruumiks sotsiaalsetes konstruktsioonides (Rendell 2008).

Angloameerika uurijate seas hoogustus avaliku ruumi teoreetiline käsitlemine 1990. aastatel, mil avalikku ruumi hakati pidama kvaliteetse linnaruumi vältimatuks osaks, seda nii füüsilise kui ka ühiskondliku sidususe eesmärgil (Zukin 1995). 1997. aastast kasutab üleilmne organisatsioon Project for Public Spaces väljendit kohaloome (ingl placemaking), et inimeste jaoks füüsilise ruumi rajamisest eristada kaasavat kohamoodustust, milles käsitletakse iga inimest kui oma kodukoha eksperti (Kent 2019). Ameerika Ühendriikides tõi avaliku ruumi mõiste laiemalt kasutusele uusurbanistide koolkond, kes rõhutas avaliku ja poolavaliku ruumi tähtsust nii kogukondlikkuse ja kodutunde tekitamiseks elamualadel kui ka võõrandumise, sotsiaalsete probleemide ja kuritegevuse ennetamiseks segregeeritud linnaruumis. Järgnevatel kümnenditel mõtestasid uurijad avalikku ruumi kitsamalt ja keerukamalt, seda nii ühiskondlikus kontekstis kui ka sotsiaalsete ja kultuuriliste tavade raames (Watson 2006). Briti linnateadlane Ali Madanipour (2003: 4) on avalikku ruumi pidanud avaliku elu osaks ning Taani arhitekti Jan Gehli (2015: 3) sõnul on avalik ruum kohtumispaik. Hiljutistes mõiste edasiarendustes on ka ajastukohast pingestumist ja uuenduslikkust, mis mõjutavad avaliku ruumi kui ühiskondliku, kõigile kuuluva hüve kasutamist (Hristova, Czepczyński 2018). Ameerika sotsioloog Sharon Zukin (2012: 31) rõhutab üleilmastumise mõjul eri linnaelementide segunemist hübriid-, suland- või globaalvormideks, mistõttu ei ole enam võimalik aru saada, kus või mis on avalik ruum. Sestap on erialaleksikasse lisandunud mõiste poolavalik ruum. 2000. aastatel valitsenud neoliberaalne lähenemine linnaruumile muutus 2010. aastatel avalikke huve arvestavamaks ning ruumi avatus ja avalikkus on linnaruumi ümberkujundamises kesksel kohal. Ühtlasi on lisandunud teooriad ja kriitika veelgi mitmekesistanud arusaama ruumist ja ruumikasutusest. Ootused avalikule ruumile on järjest kõrgemad, kuigi need ei tarvitse eraruumi pealetungis ja linnaarendustes täituda. 
Tänapäeva urbanistikas mõistetakse avalikku ruumi kui lefebvre'ilikku inimeste õigust linnale (Lefebvre 1968), mis ühelt poolt tekitab konflikte ja vaidlusi ning teiselt poolt jällegi ühendab ühiskonda (Zukin 2009). Avalikust ruumist mõeldakse kui vabadusest olla ja tegutseda linnaruumis, ometi on osa inimesi kas füüsiliselt (näiteks erivajadustega inimesed) või sotsiaalselt (rikkad-vaesed, vähemused jne) avalikust ruumist tõrjutud. Pruukides sõnu avalik, avalikkus ja kogukond, tahes-tahtmata semantiliselt dekonstrueeritakse ühiskonda. Avaliku ruumi arutelu väljendab ühiskondliku kaasatuse, võõrandumise ja hüljatuse muutusi (Lehtovuori jt 2014).

\section{Avalik ruum eesti teaduslikus ja erialakäsitluses}

Eestikeelne sõna ruum on germaani tüvega laensõna. Arhitektuuri valdkonnas on sõna koht ehitamise või sees olemise-elamise tulemus, kohas kohtuvad mõte kui mälestus ning ruum kui osalus (Soolep 2011: 72). Martin Heidegger on käsitlenud germaani ruumilisi mõisteid ja võrrelnud neid vanakreekakeelsete sõnadega:

See, milles miski saab, peab silmas toda, mida meie nimetame „ruumiks”. Kreeklastel ei ole „ruumi” jaoks sõna. See ei ole juhus; sest nad ei koge ruumilist mitte extensio'st

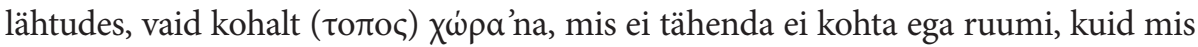
võetakse kohalseisva poolt sisse, hõivatakse. Koht kuulub asja enda juurde. Erinevatel asjadel on kunati oma koht. Sellesse kohalisse „ruumi” seatakse saav sisse ning sellest välja. Et see aga on võimalik, siis peab „ruum” olema vaba väljanägemise mis tahes viisist, mille ta peaks võima kusagilt võtta. (Heidegger 1996: 90)

Järgmisena peatume ruumi ja avaliku ruumi objektiivsusele püüdlevatel käsitlustel eesti teaduslikus ja erialases arusaamas.

\subsection{Ruumi mõiste maateaduses}

Angloameerika geograafid on aastakümneid teoreetiliselt väidelnud ruumi, koha ja maastiku tähenduste üle (Setten 2005). Eesti maateaduses on ruumi mõiste teoreetiline käsitlus olnud tagasihoidlik ja juhuslik. Mõiste on juurdunud eri ajastute juhtivate teadlaste kirjutiste ja ülikooli loengute põhjal, ent arutelu on selle ümber vähe olnud. Ruumi asemel on 1920. aastatest alates olnud Eesti maateaduse alusmõiste maastik, mida on põhjalikult üldistatud ja erinevalt käsitletud (Kurs 2000; Peil jt 2004). Eesti geograafia rajaja, soome professor Johannes Gabriel Granö tõi soome keelest siinsesse sõnavarasse mõiste ümbrus (sm ympäristö), mis laienes sisuliselt ja asendus hiljem keskkonnaga. Keskkond koondmõistena katab suuresti tänini füüsilise, aga ka sotsiaalse ruumi tähendust. Nõukogude ajal tõusis geograafiliseks alusmõisteks territoorium (Tammiksaar jt 2013). Alates 1990. aastatest, sh ka 2000. aastate erialakeele euroopastumise mõjul, on lahendatud ruumikäsitluse teoreetilisi ja mõistelisi küsimusi samuti territooriumi ja territoriaalsuse põhjal. Geoinfosüsteemide (GIS) arenguloos tuleb ruumi mõiste kasutusse eeskätt ruumiandmete 
ja -infoga seoses (Roosaare jt 2019: 107). 1970. aastatel tegeles geograafilise ruumi mõistelise, ühtlasi nii teoreetilise kui ka praktilise avamisega Jüri Jagomägi, korraldades Eesti territooriumi kompleksset hindamist ja funktsionaalset tsoneerimist. Selleks jagati ruum mõõtkava alusel 15 tasandiks (Jagomägi 2019). Tähelepanu on pälvinud ka avaliku ruumi mõõtkavad ja mitmetasandilisus. Viimastel aastatel on infotehnoloogiliste tarkvarasüsteemidega linnavalitsemises ja -korralduses kehtestunud targa linna kontseptsioon, mis avab ruumi mõiste samuti eeskätt virtuaalselt, ruumiandmete kaudu (vt Soe 2018).

Aastatel 2009-2010 peetud kaheksal linnafoorumil (Pae 2011a) väljendasid arhitektid majanduskasvujärgseid mõtteviise, mis paljuski haakusid avaliku ruumiga. Ometi ei ole avalikku ruumi konkreetse mõistena piiritletud ning mõiste sisu kandub avatult ja lahtiselt, loomingulise ja tõlgenduslikuna linnaruumi probleemikeskse käsitluse mõisteväljadesse (nt käsitledes linna avamist merele, linnaruumi tihendamist ja mitmekesistamist, eripalgeliste linnakvartalite ning uue ja vana sidumist, avalike funktsioonide lisamist, autokeskse linnaarengu ja valglinnastumise pidurdamist ning linnaruumi taaskasutamist). Linnafoorumid edendasid olulisel määral ruumiplaneerimise mõtlemist ja keelt. Avalikku ruumi on põhjalikult käsitlenud Kaja Pae (2011b), kes kahtleb inimeste võimes uut avalikku ruumi omaks võtta ning seda loominguliselt ja mitmel moel kasutada, selle asemel et olla vaid passiivses kontaktis linnaga või järgida rangelt väljakujunenud käitumismustrit (nt kaubanduskeskustes). Pae näeb ruumi julges kasutamises võimalust inimese enda individuaalsuse väljendamiseks ja avamiseks, ka ümberkujunemiseks.

\subsection{Avaliku ruumi mõiste arhitektuuris ja urbanistikas}

Kuigi arhitektuuriteoorias on ruumil keskne roll ning avalikud hooned ja väljakud on olnud arhitektuuridiskursuse osa, siis laias tähenduses avalik ruum jõudis eestikeelsesse arhitektuuridiskursusse pisteliselt 1990. aastatel ja püsivalt 2000. aastate keskel. Enne avaliku ruumi mõistet kasutati arhitektuuri perioodilistes väljaannetes mitut sarnast mõistet. Näiteks ajakirja Ehituskunst esimeses numbris 1981. aastal esinesid väljendid avalik territoorium, majadevaheline ruum ning linnaruumi kvaliteet (Vahtre 1981), mis hõlmavad ruumi laiemalt, mitte ainult arhitektuurselt projekteeritud hoonetena.

Eestikeelne termin on ingliskeelse fraasi public space otsetõlge ning see esineb ajakirjas Ehituskunst 1990. aastatel (nt Steinmann 1995) ja väliseesti tõlkeartiklites (nt Sivers 1996). Uuenduslikuna avati avalikku ruumi eesti lugejatele kogumikus „Üle majade. Linnaehituslikke projekte ja artikleid aastatest 1994-1998” (Alver jt 1999). Erialaterminina juurdus avalik ruum eesti keelde 2003. aastal, kui Ehituskunstis kasutasid seda Leonhard Lapin, Katrin Koov ja Ingrid Ruudi. Samasse aastasse jääb teadaolevalt esimene eesti keelde tõlgitud definitsioon: „Avalik ruum on eikellegimaa, mida on võimalik hõivata" (Agrest 2003).

Ajalehe Sirp veergudele jõudis avalik ruum 2000. aastate alguses. Kõigepealt kasutati seda tekstides, mis käsitlesid kultuurisündmusi ja -nähtusi (Naumanis 2002; Ligi 2004; Sobolev 2004; Soomre 2004), hiljem regulaarselt ka arhitektuurikülgedel. 
Avalikku ruumi käsitles põhjalikult 2004. aasta Vikerkaare erinumber (nr 4-5), milles Tallinna linnaruumi avaliku-privaatse olemusse süüvis Triin Ojari, üldistades: „Linnaruumiline hajusus ja määratlematus on asendunud kindla omanikusuhtega, eraomandi piiride defineerimise ja avaliku territooriumi hiiliva privatiseerimisega kommertsmaailma taktis" (2004: 92).

2018. aastal avaldas Riigikantselei juures tegutsenud interdistsiplinaarne ruumiloome ekspertgrupp lõppraporti (Riigikantselei 2018), kus on avalik ruum defineeritud tervikliku võrgustikuna, mille vajalikkuses on ühiskond kokku leppinud. Ühtlasi tõi raport kaasa uudissõna ruumiloome kasutuselevõtu.

Ruumiloome on ruumi arengut mõjutavate otsuste kujundamine ja elluviimine. [---] Ruumiloome kvaliteedi määravad sageli otsused, mis langetatakse enne ruumilise planeerimise või projekteerimisprotsessi algust ning millesse ruumipädevusega spetsialistid - ruumivaldkondade asjatundjad - enamasti kaasatud ei ole. Ruumivaldkonnad on ekspertrühma käsituses eelkõige ruumi kavandamisega seotud erialad nagu ruumiline planeerimine, arhitektuur, sisearhitektuur, maastikuarhitektuur ja disain. (Riigikantselei 2018: 5)

Eesti avalik ruum on muutumas järjest moodsamaks, kihilisemaks ja hübriidsemaks. XX sajandi suurim sotsiaalkultuuriline muutus taluühiskonna linnastumisel oli see, et töö ja koduse elu eraldumise tõttu suurenes lõhe avaliku ja privaatse sfärri vahel (Pärdi 2018). Rööbiti moderniseerumisega hakkas ühiskonnas jõudsalt suurenema anonüümsus. Järk-järgult kasvava privaatsuse vajaduse sümboliks tänapäeva Eestis on auto. See ei ole enam vahend, millega sõita punktist A punkti B, see on privaatne sotsialiseerumise ruum. Möödasõitvates autodes näeb autojuhte ja kaasreisijaid samal ajal lõunat söömas, kohvi joomas, muusikat kuulamas. Auto on kui kodu või kontor, mis liigub avalikus ruumis, tänavatel. Seeläbi on avalik ruum muutunud justkui elutoa ja köögi pikenduseks. Samal ajal istuvad inimesed tundide kaupa kohvikutes ja kaubanduskeskustes ning, kasutades arvuteid ja nutiseadmeid, teevad „avatud kontoris” tööd või veedavad niisama aega. Tänaval kõndides võib korraga süüa, juua ning telefoniga rääkida, mis veel 30 aastat tagasi ei sobinud siinsesse kombe- ja käitumisruumi. Isiklike tegevuste avalikustamine võib tekitada ruumikasutuses probleeme, aga ka luua uusi tähendusi, andes ühtlasi märku, et kultuurimustrite muutumisega muutub ka suhtumine ruumi. Nii kujundabki era- ja avaliku sfääri vaheline pinge Eesti avaliku ruumi tähendust.

Ka Eesti inimarengu aruanne (Sooväli-Sepping 2020) seadis eesmärgiks käsitleda avalikku ruumi mitmekülgselt, liikudes sisus sügavamale lihtsakoelisest urbanistlikust avaliku ja eraruumi vastandusest. Füüsiline ja digitaalne avalik ruum, selle korrastatuse viisid ja ligipääsetavus mõjutavad ühiskondlikke protsesse. Seetõttu laiendab aruanne avaliku ruumi mõistet mõõtkava alusel ning katab geograafiliselt kogu Eesti: asustusstruktuuri, loodusalad ja linnaruumi, sealhulgas linnakvartalid, hoonestiku ja linnadisaini. Peale selle käsitletakse aruandes avalikku ruumi ka mõttelises ja virtuaalses võtmes aruteluruumina (Ibrus 2020). Ühisteemana kerkib viies peatükis küsimus demokraatlikest ruumisuhetest. Avalikus ruumis eeldatakse täie- 
likku avatust, ehkki enamasti pole võimalik seda pakkuda. Füüsilist avalikku ruumi käsitlevad ülevaated lähtuvad tõdemusest, et ehkki praegu kuulub 40\% Eesti maaressursist riigiomandisse ja $1 \%$ omavalitsustele, võib ka selle ruumi avalikkus olla piiratud, näiteks lasteaed koos mänguhooviga, või välistatud, näiteks riigikaitsemaa (väeosade territooriumid). Samuti võidakse avalikku huvi tunda selle Eesti territooriumi 59\% vastu, mis on eraomand: avalikkusel on ootus seda kasutada ning ta võib selle toimimist suunata. Ruum on avalik niivõrd, kuivõrd avalik sektor selle kasutust seadusandlusega suunab või piirab. Iseküsimus on, kes ja kuidas omandi valdust kasutab. Toomas Paaver ja Elo Kiivet (2020) tõdevad, et avaliku ruumi mõistet alles teadvustatakse, ning peavad avalikku ruumi ühiskonna ja demokraatia tervise väljenduseks ja mõõdupuuks.

\subsection{Avalik ruum õigusterminoloogias}

Avalikku ruumi õigusmõistena ei ole olemas. See-eest määratles 2002. aastani kehtinud asjaõigusseaduse $\$ 9$ „Üldine, avalik ja eraasi” avaliku asja:

(2) Avalik asi on asi, mis kuulub riigi- või munitsipaalomandisse ja on oma ühiskondliku olemuse tõttu kasutatav igaühe poolt nagu territoriaal- ja sisemeri, laevatatavad veekogud, avalikud tänavad, väljakud ja pargid. (Asjaõigusseadus: 2)

Selles väljendub ka avaliku ruumi olemus. Sama paragrahvi neljandas lõikes kinnitati olulise aspektina, et üldine ja avalik asi ei ole tsiviilkäibes.

Praegu kehtiv asjaõigusseaduse $\$ 142$ kehtestab kinnisasjal viibimise õigused, mille kohaselt ei ole õigust omaniku loata viibida piiratud või tähistatud kinnisasjal. Piiramata alal ei või omaniku loata viibida päikeseloojangust päikesetõusuni. Sellega on seatud ka ruumikasutuse aluspõhimõte. Planeerimisseadus avalikku ruumi ei reguleeri. Selle $\$ 10$ rõhutab küll, et planeerija peab arvesse võtma erinevaid huve, sealhulgas avalikke huve ja väärtusi, kaaluma neid vastavalt planeerimise põhimõtetele ja planeeringu eesmärkidele ning lõimima need planeeringulahendusse. Asjaolu, et Eesti õigussüsteemist on sõnapaar avalik ruum välja jäetud, süvendab ebamäärasust ja loob mitmesuguseid tõlgendusi. Aja jooksul on ruumikasutus üha olulisemaks muutunud, mistõttu väärib avalik ruum juriidilist staatust ja selgitamist võimalikes planeerimisseaduse uuendustes.

Seoses riigisaladuse ja heakorraga on avalikku ruumi määratletud Eesti üksikutes õigusaktides:

ala, mis ei ole turva- ega administratiivala (Riigisaladuse... 2007);

igaühele, sõltumata soost, vanusest ja muudest omadustest, ligipääsetav ja piiranguteta kasutatav ruum (teed, tänavad, haljasalad, bussipeatused), samuti poolavalik ruum, mille kasutamine võib olla tingitud ajast, loast jms. (asutuste territooriumid, turg, õuealad, rannad jne) (Muhu valla... 2014). 
Osaliselt katab avalikku ruumi avaliku koha õigusmõiste. Avalikus ruumis kehtib avalikus kohas käitumise õigusnorm, see, mida tohib avalikus kohas teha, mida mitte, kuidas on reguleeritud ürituste korraldus jm ruumihaldus. Korrakaitseseaduse järgi on avalik koht määratlemata isikute ringi kasutatav maa-ala, ehitis, ruum või selle osa, ühissõiduk. Avalikus kohas on keelatud käituda teist isikut häirival viisil (st nii, et avaliku koha kasutamine on häiritud): solvata sõnaga, žestiga või muul moel, hirmutada, ähvardada, avalikus kasutuses olevat asja reostada, rikkuda ja hävitada või kasutada seda muul eesmärgil, samuti on keelatud alkoholi tarvitamine. Avaliku korra rikkumise süütegude tuvastamisel ja menetlemisel on karistusseadustiku $₫ 262$ järgi peamine küsimus selles, kas süütegu pandi toime avalikus kohas.

Samuti on mõistekasutust kujundamas selge tähendusega sõna õu. Kehtiv liiklusseadustik näiteks sõnastab õueala kui avaliku ruumi laiendatud mõiste: see on ,jalakäijate ja sõidukite samaaegselt liiklemiseks ettenähtud ala, kus ehituslike või muude vahenditega on vähendatud sõidukite kiirust ning mille sisse- ja väljasõiduteed on tähistatud õueala liikluskorda kehtestavate liiklusmärkidega" (Liiklusseadus $\$ 2,96$ ). Õueala (holl woonerf 'elav õu') põhimõte linnaplaneerimises pärineb 1970. aastate alguse Hollandist, kus tollastes uuselamukvartalites tekkis vajadus korraldada vähekaitstud liiklejate ja sõidukite liikumine. Avaliku ruumi või hoonete ümbruse määratlemine õuealana lähtub segaliikluse reguleerimise vajadusest. Eramaal jääb õuel liikumine eraomaniku korraldada. Enamasti on siiski õueala avalik ruum.

\section{Kokkuvõte - avaliku ruumi tähendused ühiskondlikes protsessides}

Artikli eesmärk ei ole leida üht suurt avaliku ruumi narratiivi, vaid juhtida tähelepanu mõiste mitmekülgsusele ja rikkusele nii laiemas kui ka Eesti akadeemilises diskursuses. Avalik ruum on eesti keele eri valdkondades kiirelt arenev mõiste. Artiklis tõdeme, et avalik ruum raamistab ühiskonna ja selle kogukondade ühteja kokkukuuluvust. Avalikus ruumis väljenduvad ja kujunevad sotsiaalsed normid, väärtused ja hoiakud, mis omakorda lähtuvad demokraatlikus ühiskonnas kodanikkonna huvidest. Mida avatum ja demokraatlikum on ühiskond, seda paremad on kaasarääkimise võimalused ruumi kujundamisel ja seda läbipaistvamad on ruumi puudutavad otsused. Ruum ise mõjutab inimeste käitumist ning kujundab nii kollektiivset kui ka üksikisiku mõtteviisi. Avalik ruum on inimestele midagi enamat kui lihtsalt füüsiline ruum: see on tähenduslik, kujutluslik ja sümboolne (Watson 2002: 55). Sotsiaalteoreetikud on vaadelnud avalikku ruumi ka mikropoliitika teostamise paigana, kus eri arusaamad ja huvid ning linnakasutuse paljusus tekitavad vastuolusid ja konflikte (Tonkiss 2005: 59). Seda kinnitavad kodanikuaktivismi väljendused ja asumiseltside tegevus.

Artiklis on esile tõstetud mõiste ambivalentsus. Kui koht on seotud identiteedi ja sotsiaalsete suhetega, siis mis on ruumi tähendusväli? Veelgi enam, võime küsida, mis või kes on avalikkus ruumis. Ruum viitab abstraktsele füüsilisele asendilisusele koos kõige selles sisalduvaga. Ruum saab kohaks, kui inimesed annavad sellele 
tähenduse. Samal ajal väidavad teadlased ja eksperdid, et avaliku ruumi olemusse kuulub kodanike koosloome ja kaasatus (Tonkiss 2005). Seetõttu jäävad ka Eestis õhku nii teoreetilised kui ka õiguslikud küsimused: kas avalik ruum ja avalik koht on sünonüümid? Kuidas mõistavad ruumi arhitektid ning mis tähendustes räägivad sellest planeerijad ja maateadlased? Selgust aitavad lisada mõisted kohaloome ja ruumiloome, millest esimene viitab selgemalt tähendustega katmisele ja identiteedi tähtsusele, teine pigem füüsilise keskkonna arendusele. Ühtset akadeemilist definitsiooni pole eestikeelsetes ringkondades ka koolkonniti, ei maateaduses ega ka arhitektuuris ja urbanistikas. Teisalt, kui räägitakse avalikust ruumist, tähendab see eesti keeles üldjuhul linnaruumi. Seetõttu võime väita, et avaliku ruumi tähendusväli on enamasti piiritletud linna kui haldusüksuse piiriga või hoonestatud linnalise keskkonnaga. Praeguses seadusandluses on avaliku ruumi mõiste juriidiliselt katmata. Samal ajal jätab see võimaluse mõistega uuenduslikult ümber käia ja seda loovalt sisustada. Avaliku ruumi kasutus põhinebki tavadel ning harjumustel, niisamuti reeglitel ja eeskirjadel. Avalik ruum väljendab seega ühiskonna sidusust ja üldjuhul kujunebki ühisloome viljana (Ermacora, Bullivant 2016: 9).

Ühiskondlikud väärtused ja aktuaalsed ruumiprotsessid saavad eestikeelses ruumi mõistes lähiaastail kindlasti senisest selgemalt ja täpsemalt väljendatud. Nii teadlikkus kui ka teadmus avalikust ruumist on kasvamas.

Täname anonüümset retsensenti. Artikkel on kirjutatud Eesti Teadusagentuuri projekti
„Maastikuline lähenemine rurbaansusele" (PRG398) raames.

\section{VEEBIVARAD}

EKI ühendsõnastik 2020. Eesti Keele Instituut, Sõnaveeb 2020. https://sonaveeb.ee

Esterm. Eesti Keele Instituudi mitmekeelne terminibaas. https://termin.eki.ee/esterm

\section{KIRJANDUS}

Agnew, John A. 1987. Place and Politics. The Geographical Mediation of State and Society. London: Routledge.

Agrest, Diana 2003. Arhitektuur väljastpoolt: keha, loogika ja sugu. - Ehituskunst, nr 39-40. http://ehituskunst.ee/diana-agrest-arhitektuur-valjastpoolt-keha-loogika-ja-sugu (21. VII 2020).

Alver, Andres; Kaasik, Veljo; Trummal, Tiit 1999. Üle majade. Linnaehituslikke projekte ja artikleid aastatest 1994-1998. Tallinn: Alver ja Trummal Arhitektuuribüroo.

Asjaõigusseadus. Vastu võetud 9. VI 1993, jõustumine 1. XII 1993. Redaktsiooni jõustumise kp: 1. VI 2002. Redaktsiooni kehtivuse lõpp: 30. VI 2002. https://www.riigiteataja. ee/akt/22252.pdf

Augé, Marc 2012. Kohad ja mittekohad. Tlk Anti Saar. (Bibliotheca controversiarum.) Tallinn: Tallinna Ülikooli Kirjastus.

Ermacora, Thomas; Bullivant, Lucy 2016. Recoded City. Co-creating Urban Futures. London: Routledge. 
Gehl, Jan 2015. Linnad inimestele. Tlk Kristjan Teder. Tallinn: Eesti Kunstiakadeemia Kirjastus.

Gieryn, Thomas F. 2003. A space for place in sociology. - Annual Review of Sociology, kd 26, lk 463-496.

Heidegger, Martin 1996. Sissejuhatus metafüüsikasse. Tlk Ülo Matjus. (Avatud Eesti raamat.) Tartu: Ilmamaa.

Hristova, Svetlana; Czepczyński, Mariusz 2018. Public Space. Between Reimagination and Occupation. (Design and the Built Environment.) New York: Routledge.

Ibrus, Indrek 2020. Sissejuhatus. - Eesti inimarengu aruanne 2019/2020. Linnastunud ühiskonna ruumilised valikud. Toim Helen Sooväli-Sepping. Tallinn: SA Eesti Koostöö Kogu, lk 204-210.

Jagomägi, Jüri 2019. Planeerimisalastest uuringutest kaardifirma Regio'ni. - Eesti Geograafia Seltsi aastaraamat 2019, kd 44. Tallinn: Eesti Geograafia Selts, lk 236-270.

Kalm, Mart 2014. Võim ruumis. - Vaba ruum. Essee digitaalsest \& avalikust. Toim Johanna Jõekalda, Johan Tali, Siim Tuksam. Tallinn: Eesti Arhitektuurikeskus \& Lugemik, lk 98-111.

Kaminer, Tahl 2017. The Efficacy of Architecture: Political Contestation and Agency. LondonNew York: Routledge.

Kent, Ethan 2019. Leading urban change with people powered public spaces. The history, and new directions, of the Placemaking movement. - The Journal of Public Space, kd 4, lk 127-134.

Kriis.ee. https://kkk.kriis.ee/et/kkk/22-reegel-piirangud-kaubanduskeskustes-soogikohtades-ja-mujal/2--2-reegel-ja-erandid (23. VI 2020).

Kurs, Ott 2000. Inimgeograafia Eestis. - Inimesed, ühiskonnad ja ruumid. Inimgeograafia Eestis. Toim Jussi Jauhiainen, Hill Kulu. Tartu: Tartu Ülikooli Kirjastus, lk 24-37.

Lapin, Leonhard 2014. Avalik ruum. - Vaba ruum. Essee digitaalsest \& avalikust. Toim Johanna Jõekalda, Johan Tali, Siim Tuksam. Tallinn: Eesti Arhitektuurikeskus \& Lugemik, lk 66-75.

Lefebvre, Henri 1968. Le Droit à la ville. Paris: Anthropos.

Lefebvre, Henri 1991. The Production of Space. Oxford: Blackwell.

Lehtovuori, Panu; Kurg, Andres; Schwab, Martina; Ermert, Siri 2014. Public spaces, experience and conflict: The cases of Helsinki and Tallinn. - Public Space and Relational Perspectives: New Challenges for Architecture and Planning. Toim Chiara Tornaghi, Sabine Knierbein. New York: Routledge, lk 125-147.

Ligi, Airi 2004. Elamus. - Sirp 16. I, lk 7.

Liiklusseadus. Vastu võetud 17. VI 2010, jõustumine 1. VII 2011. https://www.riigiteataja.ee/ akt/117032011021

Low, Setha; Smith, Neil (toim) 2006. The Politics of Public Space. New York: Routledge.

Madanipour, Ali 2003. Public and Private Spaces of the City. London-New York: Routledge.

Madden, David J. 2017. The contradictions of urban public space: The view from London and New York. - The SAGE Handbook of the 21st Century City. London: SAGE, lk 535-551.

Meyers, Gretchen E. 2005. Vitruvius and the origins of Roman spatial rhetoric. - Memoirs of the American Academy in Rome, kd 50, lk 67-86. 
Muhu valla heakorra- ja kaevetööde eeskiri. Vastu võetud 21. IX 2007. https://www.riigiteataja.ee/akt/429012013111

Muudame maailma: säästva arengu tegevuskava aastaks 2030. https://www.riigikantselei.ee/sites/default/files/content-editors/Failid/SA_eesti/saastva_arengu_tegevuskava_2030_uro_et.pdf (12. VIII 2020).

Naumanis, Normunds 2002. Balti sängi keskel. Noored lavastajad võtavad läti teatris kasutusele uusi mõõdupuid, puhuvad uued tuuled. - Sirp 29. IX, lk 14.

Neal, Zachary 2010. Urban space. - Encyclopedia of Urban Studies, kd 2. Toim Ray E. Hutcinson. London: Sage, lk 927-930.

Ojari, Triin 2004. Linnaruumilistest muutustest 1990. aastate Tallinnas. - Vikerkaar, nr 4-5, lk 91-97.

Paaver, Toomas; Kiivet, Elo 2020. Avalik ruum kui elukeskkonda siduv võrgustik. - Eesti inimarengu aruanne. Linnastunud ühiskonna ruumilised valikud. Toim Helen SooväliSepping. Tallinn: SA Eesti Koostöö Kogu, lk 105-115.

Pae, Kaja (toim) 2011a. Linnafoorumid. Urban Forum. Tallinn: Eesti Arhitektuurikeskus.

Pae, Kaja 2011b. Tunda ära korratamatut. - Linnafoorumid. Urban Forum. Toim Kaja Pae. Tallinn: Eesti Arhitektuurikeskus, lk 20-30.

Parkinson, John R. 2013. How is space public? Implications for spatial policy and democracy. - Environment and Planning C: Government and Policy, kd 31, lk 682-699.

Peil, Tiina; Sooväli, Helen; Palang, Hannes; Oja, Tõnu; Mander, Ülo 2004. Estonian landscape study: contextual history. - Belgeo, nr 2-3, lk 231-244.

Pärdi, Heiki 2018. Eesti argielu. Teekond moodsasse maailma. Tallinn: Tänapäev.

Rendell, Jane 2008. Space, place, site: critical spatial practice. - The Practice of Public Art. (Routledge Research in Cultural and Media Studies.) Toim Cameron Cartiere, Shelly Willis. London: Routledge, lk 33-55.

Riigikantselei 2018. Ruumiloome ekspertrühm. Lõpparuanne. https://www.riigikantselei.ee/ sites/default/files/riigikantselei/strateegiaburoo/ruumiloome_lopparuanne_.pdf (26. VI 2020).

Riigisaladuse ja salastatud välisteabe kaitse kord. Vastu võetud 20. XII 2007. https://www. riigiteataja.ee/akt/12903659

Roosaare, Jüri; Mõisja, Kiira; Aunap, Raivo 2019. Geoinformaatika. Õpik kõrgkoolidele. Tartu: Tartu Ülikooli Kirjastus.

Setten, Gunhild 2005. Who owns concepts? Notes on the product, practice, property and power of writing. - Landscape, Law, and Justice. Proceedings of a conference organised by the Centre for Advanced Study at the Norwegian Academy of Science and Letters Oslo 15-18 June 2003. Toim Tiina Peil, Michael Jones. Oslo: Novus forlag, lk 3-13.

Sivers, Fanny de 1996. Keskaegne Pergonges. - Ehituskunst, nr 13, lk 11-17.

Sobolev, Mari 2004. Õudustundega haaras ta kaamera... - Sirp 12. III, lk 8.

Soe, Ralf-Martin 2018. A Tale of Two Smart Cities. How Virtual Walls between Cities can Fall. (Tallinn University of Technology doctoral thesis 10/2018.) Tallinn: TTÜ Press.

Soolep, Jüri 2011. Ruum ja mõte. 10 loengut arhitektuurist. Tallinn: Eesti Kunstiakadeemia Kirjastus.

Soomre, Maria 2004. Rulaga muuseumis. - Sirp 27. II, lk 11. 
Sooväli-Sepping, Helen 2011. Kultuurigeograafia. - Humanitaarteaduste metodoloogia. Uusi väljavaateid. (Gigantum humeris.) Toim Marek Tamm. Tallinn: Tallinna Ülikooli Kirjastus, lk 170-186.

Sooväli-Sepping, Helen (toim) 2020. Eesti inimarengu aruanne 2019/2020. Linnastunud ühiskonna ruumilised valikud. Tallinn: SA Eesti Koostöö Kogu.

Steinmann, Georg 1995. Ruumi naasmine. - Ehituskunst, nr 12, lk 5-9.

Zukin, Sharon 1995. The Cultures of Cities. Cambridge: Blackwell.

Zukin, Sharon 2009. The Naked City: The Death and Life of Authentic Urban Places. New York: Oxford University Press.

Zukin, Sharon 2012. Competitive globalization and urban change: The allure of cultural strategies. - Rethinking Global Cities: Insights from Secondary Urban Centers. Toim Xiangming Chen, Ahmed Kanna. New York: Routledge, lk 17-34.

Tammiksaar, Erki; Pae, Taavi; Kurs, Ott 2013. Continuity of ideas? Salme Nõmmik, Edgar Kant and the development of economic geography in Soviet Estonia. - Geografiska Annaler Series B-Human Geography, kd 95, nr 1, lk 51-70.

Tonkiss, Fran 2005. Space, the City and Social Theory: Social Relations and Urban Forms. Cambridge: Polity Press.

Vahtre, Silver 1981. Linnakujundusest Tallinnas. - Ehituskunst, nr 1, lk 82-83.

Watson, Sophie 2002. The public city. - Understanding the City. Toim John Eade, Christopher Mele. Oxford: Blackwell, lk 49-65.

Watson, Sophie 2006. City Publics. The (Dis)Enchantments of Urban Encounters. LondonNew York: Routledge.

Antti Roose (snd 1964), PhD, Tartu regionaalse energiakeskuse projektijuht (Narva mnt 3, 50009 Tartu), antti.roose@trea.ee

Helen Sooväli-Sepping (snd 1974), PhD, Tallinna Ülikooli professor, vanemteadur, jätkusuutliku arengu prorektor (Narva mnt 25, 10120 Tallinn), helen.soovali@tlu.ee

Anni Müüripeal (snd 1992), MA, Tallinna Ülikooli tervisekäitumise ja heaolu doktorant, nooremteadur (Narva mnt 25, 10120 Tallinn), annim@tlu.ee 


\section{Public space: the development of the concept and its semantic fields}

Keywords: public space, place, architecture, urbanism, geography

Over the last five years, the Estonian society has begun to pay more attention to the environment we live, work and relax in. The use of the concept of 'space' and its association with the word 'public' is a practical problem on the way to a common understanding of space and its use. The ambiguity of the concept of space must be taken into account, both in everyday language and in scientific language. The concept of 'public space' is a rapidly developing concept in various fields in the Estonian language, yet in today's legislation this is not legally covered. There is no well-established definition of 'public space' in Estonia. In mapping the use of 'public space', this article is confined to geographical sciences, urbanism and architecture. We cover the concept of 'public space' in the spatial sciences and discuss its social significance, analysing the semantic fields of the term and describing the contexts of its use. The article does not claim to invent a grand narrative of 'public space', but rather draws attention to the diversity and richness of the concept in academic discourse in general and in the Estonian context in particular. These ambiguities open up the possibility of innovating the concept and creatively using it in practice.

Antti Roose (b. 1964), PhD, Tartu Regional Energy Agency, Project Manager (Narva mnt 3, 50009 Tartu), antti.roose@trea.ee

Helen Sooväli-Sepping (b. 1974), PhD, Tallinn University, Professor, Senior Researcher, Vice-Rector for Sustainable Development (Narva mnt 25, 10120 Tallinn), helen.soovali@tlu.ee

Anni Müüripeal (b. 1992), MA, Tallinn University, PhD Student in Health Behaviour and Well-Being, Junior Researcher (Narva mnt 25, 10120 Tallinn), annim@tlu.ee 